\title{
References
}

\section{BOOKS AND ARTICLES}

Aagaard, Jørgen, Lars Merinder, and Dorthe Mundbjerg. 2009. Psykoedukation. In Psykiatrisk Sygepleje. Niels Buus, ed. Pp. 364-82. Copenhagen: Dansk Sygeplejeråd and Nyt Nordisk Forlag Arnold Busck.

Abu-Lughod, Lila. I986. Veiled Sentiments: Honor and Poetry in a Bedouin Society. Berkeley: University of California Press.

Adorno, Theodor W. 1984. Aesthetic Theory. C. Lenhardt, trans. London and Boston: Routledge and Kegan Paul.

Al-Ghazali, Abu Hamid Muhammad. 1989[1058-IIII C.E.]. The Remembrance of Death and the Afterlife. T. Winter, trans. Cambridge: Islamic Texts Society.

Al-Issa, Ihsan. 2000. Preface. In Al-Junūn: Mental Illness in the Islamic World. Ihsan Al-Issa, ed. Pp. xiii-xv. Madison: International Universities Press.

Al-Jawziyah, Ibn Qayyim. 2003[I292-I350 C.E.]. Healing with the Medicine of the Prophet. Abdul Rahman Abdullah, ed. Jalal Abual Rub, trans. Riyadh: Darussalam.

Altorki, Soraya. 1986. Women in Saudi Arabia: Ideology and Behavior among the Elite. New York: Columbia University Press.

Anderson, Benedict. I991. Imagined Communities: Reflections on the Origin and Spread of Nationalism. New York: Verso Books.

Arnheim, Rudolf. 1957. Film as Art. Berkeley: University of California Press.

Asad, Talal. 2003. Formations of the Secular: Christianity, Islam, Modernity. Stanford: Stanford University Press.

Axinn, Sidney. 20I0. Sacrifice and Value: A Kantian Interpretation. Lanham and Plymouth: Lexington Books.

Badeen, Edward and Birgit Krawietz. 2003. Islamic Reinvention of Jinn: Status-Cut and Success Story. In Identidades Marginales. Cristina de la Puente, ed. Pp. 93-I09. Madrid: Consejo Superior de Investigaciones Cientificas.

Baker, C. Bruce, Michael Johnsrud, Lynn Crismon, Robert Rosenheck, and Scott Woods. 2003. Quantitative Analysis of Sponsorship Bias in Economic Studies of Antidepressants. The British Journal of Psychiatry I83 (6): 498-506.

Bankovsky, Miriam. 2004. A Thread of Knots: Jacques Derrida's Homage to Emmanuel Levinas's Ethical Reminder. Invisible Culture 8: I-I9.

Barker, Phil and Poppy Buchanan-Barker. 2009. En Søgen efter Personen:Tidal-Modellen og Holistisk Assessment. In Psykiatrisk Sygepleje. Niels Buus, ed. Copenhagen: Dansk Sygeplejeråd og Nyt Nordisk Forlag Arnold Busck.

Barnes, John A. 1987. Edward Evan Evans-Pritchard, I902-I973. Proceedings of the British Academy LXXIII: 447-90.

Barth, Fredrik. 1966. Models of Social Organization. London: Royal Anthropological Institute. . 1987. Cosmologies in the Making: A Generative Approach to Cultural Variation in Inner New Guinea. Cambridge: Cambridge University Press.

Barthes, Roland. 20I0[1980]. Camera Lucida: Reflections on Photography. Richard Howard, trans. New York: Farrar, Straus and Giroux.

Basso, Elisabetta. 2oII. Maurice Merleau-Ponty: Kierkegaard's Influence on His Work. Kierkegaard and Existentialism 9: 233-6I. 
Bataille, George. I99I[1967]. The Accursed Share:Volume 1: Consumption. Robert Hurley, trans. New York: Zone Books.

Bazin, André. 2005[1967]. What is Cinema? Volume 1. Hugh Gray, trans. Berkeley: University of California Press.

BBC News. 20I2. Naila Mumtaz Murder: Four Family Members Jailed For Life. Newspaper article. Retrieved II October 20I8. www.bbc.co.uk/news/uk-englandbirmingham-19699500

Behrend, Heike, Anja Dreschke, and Martin Zillinger, eds. 20I5. Trance Mediums and New Media: Spirit Possession in the Age of Technical Reproduction. New York: Fordham University Press.

Bektovic, Safet. I999. The Doubled Movement of Infinity in Kierkegaard and in Sufism. Islam and Christian-Muslim Relations I0: $325-37$.

Benjamin, Walter. I968. The Work of Art in the Age of Mechanical Reproduction. In Illuminations. Hannah Arendt, ed. and trans. Pp. 2II-44. London: Fontana.

Berenson, Alex. 2007. Lilly Settles with I8,ooo over Zyprexa. New York Times. Retrieved 8 March 20I3. www.nytimes.com/2007/or/o5/business/osdrug.html?_r=0

Bille, Mikkel and Tim Flohr Sørensen. 2007. An Anthropology of Luminosity: The Agency of Light. Journal of Material Culture I2(3): 263-84.

Blanchot, Maurice. 1993[1969]. The Infinite Conversation. Susan Hanson, trans. Minneapolis: University of Minnesota Press.

Bloch, Maurice. 1992. Prey into Hunter: The Politics of Religious Experience. Cambridge: Cambridge University Press.

Bloom, Floyd E. 20Io. Placebo Versus Antidepressant Review:The Emperor's New Drugs: Exploding the Antidepressant Myth. Cerebrum. Retrieved 8 March 20I3. http:// dana.org/news/cerebrum/detail.aspx?id=28024

Boddy, Janice. 1989. Wombs and Alien Spirits: Women, Men, and the Zār Cult in Northern Sudan. Madison: The University of Wisconsin Press.

- 1994. Spirit Possession Revisited: Beyond Instrumentality. Annual Review of Anthropology 23: 407-34.

Boe, Carolina Sanchez. 2017. From Jyllands-Posten to Charlie Hebdo: Domesticating The Muhamed Cartoons. In Suis-je Charlie? Politics and Media after the Paris Attacks. Gavan Titley, Des Freedman, Gholam Khiabany, and Aurélien Mondon, eds. London: Zed Books.

Boe, Carolina Sanchez and Peter Hervik. 2008. Integration through Insult. In Transnational Media Events. The Mohammed Cartoons and the Imagined Clash of Civilizations. Elizabeth Eide, Risto Kunelius, and Angela Phillips, eds. Pp. 213-34. Nordicom: Gothenburg.

Borberg, Hjarn v. Zernichow. 20I6. Nydansk: Er nydanskere og danskere virkelig så forskellige? Copenhagen: Multivers.

Borges, Jorge L. 197I. The Aleph and Other Stories 1933-1969: Together with Commentaries and an Autobiographical Essay. Norman Thomas di Giovanni, ed. and trans. London: Jonathan Cape.

Boseley, Sarah. 20I8. The Drugs Do Work: Antidepressants Are Effective, Study Shows. The Guardian. 2I February 20I8. Retrieved Is January 20I9. www.theguardian.com/ science/20I8/feb/2I/the-drugs-do-work-antidepressants-are-effective-study-shows

Bourdieu, Pierre. I977. Outline of a Theory of Practice. Cambridge: Cambridge University Press.

Breggin, Peter. 2008. Brain Disabling Treatments in Psychiatry: Drugs, Electroshock, and the Psychopharmaceutical Complex. New York: Springer Publishing Company.

Bruns, Gerald A. 2006. The Concepts of Art and Poetry in Emmanuel Levinas's Writings. In The Cambridge Companion to Levinas. Simon Critchley and Robert Bernasconi, eds. Pp. 206-33. Cambridge: Cambridge University Press.

Bubandt, Nils. 2009. Interview with an Ancestor: Spirits as Informants and the Politics of Possession in North Maluku. Ethnography IO(3): 29I-3I6.

. 20I4. The Empty Seashell: Witchcraft and Doubt on an Indonesian Island. Ithaca: Cornell University Press. 
Bubandt, Nils, Mikkel Rytter, and Christian Suhr. 20I7. A Second Look at Invisibility: Al-Ghayb, Islam, Ethnography. Contemporary Islam, e-publication ahead of print: I-I6.

Buck-Morss, Susan. 1991. The Dialectics of Seeing: Walter Benjamin and the Arcades Project. Cambridge, MA: MIT Press.

Callan, Alyson. 20I2. Patients and Agents: Mental Illness, Modernity and Islam in Sylhet, Bangladesh. New York: Berghahn Books.

Candea, Matei. 20II. Endo/Exo. Common Knowledge I7(I): I46-50.

Carter, Jeffrey. 2003. General Introduction. In Understanding Religious Sacrifice: A Reader. Jeffrey Carter, ed. Pp. I-II. New York: Continuum.

Castaing-Taylor, Lucien. I996. Iconophobia. Transition 69: 64-88.

Christensen, Mette Vedsgaard. 2003. Etnolekt i Århus Vest: Morfologiske, Syntaktiske og Pragmatiske Træk. In Rapport fra MUDS 9. Aarhus: Institut for Nordisk Sprog og Litteratur, Aarhus Universitet.

Cipriani, Andrea, Toshi A. Furukawa, Georgia Salanti, Anna Chaimani, Lauren Z. Atkinson, Yusuke Ogawa, Stefan Leucht, Henricus G. Ruhe, Erick H.Turner, Julian P. Higgins, Matthias Egger, Nozomi Takeshima, Yu Hayasaka, Hissei Imai, Kiyomi Shinohara, Aran Tajika, John P. A Loannidis, and John R. Geddes. 20I8. Comparative Efficacy and Acceptability of 2I Antidepressant Drugs for the Acute Treatment of Adults with Major Depressive Disorder: A Systematic Review and Network Meta-analysis. The Lancet. 39I(IOI28): I357-66.

Clifford, James and George E. Marcus, eds. 1986. Writing Culture: The Poetics and Politics of Ethnography. Berkeley: University of California Press.

Connor, Linda, Timothy Asch, and Patsy Asch. 1986. Jero Tapakan: Balinese Healer: An Etnographic Film Monograph. Cambridge: Cambridge University Press.

Crapanzano,Vincent. 1973. The Hamadsha: A Study in Moroccan Ethnopsychiatry. Berkeley: University of California Press.

- I985. Tuhami: Portrait of a Moroccan. Chicago: University of Chicago Press.

Crapanzano, Vincent and Vivian Garrison, eds. I977. Case Studies in Spirit Possession. New York: Wiley.

Csordas, Thomas. 1987. Health and the Holy in African and Afro-American Spirit Possession. Social Science and Medicine 24(I): I-II.

- I990. Embodiment as a Paradigm for Anthropology. Ethos I8(I): 5-47.

. 1997. The Sacred Self: A Cultural Phenomenology of Charismatic Healing. Berkeley: University of California Press.

Daily Mail. 20Ir. Muslim Mother Stabbed Daughter 40 Times and Cut Out Her Liver in Ritual Killing to 'Exorcise Evil Spirits'. Newspaper article. Retrieved II October 20I8. www.dailymail.co.uk/news/article-2043813/Muslim-mother-stabbed-daughter40-times-exorcise-evil-spirits-body.html

. 20I2. Muslim Woman 'Beaten with Walking Stick in Brutal Exorcism by Husband and Family who were Convinced She was Possessed by Demon'. Newspaper article. Retrieved II October 20I8. www.dailymail.co.uk/news/article-2204968/Muslimwoman-beaten-walking-stick-brutal-exorcism-husband-family-members-convincedpossessed-demon.html

Danish Council of Ethics. 20I2. Mødet med Patienten og Kulturen i Psykiatrien: Magt og Afmagt i Psykiatrien. Policy paper. Retrieved Is January 20I9. www.etiskraad.dk/ / media/Etisk-Raad/Etiske-Temaer/Psykiatri/Publikationer/20I2-06-I9-patientenkulturen-psykiatrien.pdf

De Hert, Marc, Christoph U. Correll, and Dan Cohen. 20Io. Do Antipsychotic Medications Reduce or Increase Mortality in Schizophrenia? A Critical Appraisal of the FIN-II Study. Schizophrenia Research II7(I): 68-74.

Dein, Simon and Abdool Samad Illaiee. 20I3. Jinn and Mental Health: Looking at Jinn Possession in Modern Psychiatric Practice. The Psychiatrist Online 37(9): 290-3.

Dein, Simon, Malcolm Alexander, and A. David Napier. 2008. Jinn, Psychiatry and Contested Notions of Misfortune among east London Bangladeshis. Transcultural Psychiatry 45(I): 3I-55. 
Deleuze, Gilles. 2005a[1986]. Cinema 1:The Movement-Image. Hugh Tomlinson and Barbara Habberjam, trans. London: Continuum.

- 2005b[1989]. Cinema 2: The Time-Image. Hugh Tomlinson and Robert Galeta, trans. London: Continuum.

Dillon, Martin C. 1983. Merleau-Ponty and the Reversibility Thesis. Man and World I6(4): $365-88$.

Doucet, Mathieu, and Sergio Sismondo. 2008. Evaluating Solutions to Sponsorship Bias. Journal of Medical Ethics 34(8): 627-30.

Douglas, Mary. 2002[1966]. Purity and Danger: An Analysis of Concept of Pollution and Taboo. London: Routledge.

Drachman, Hans, and Sebastian Goos. 20I2. Psykisk Syge Dør Af Medicinen. Newspaper article. Politiken. Retrieved 7 March 20I3. http://politiken.dk/indland/ECEI754922/ psykisk-syge-doer-af-medicinen/

Drieskens, Barbara. 2008. Living with Djinns: Understanding and Dealing with the Invisible in Cairo. London: Saqi Books.

Durkheim, Émile. 2008[1912]. The Elementary Forms of Religious Life. Carol Cosman, trans. Oxford: Oxford University Press.

Edgerton, Robert B. 197I. A Traditional African Psychiatrist. Southwestern Journal of Anthropology 27(3): 259-78.

Eisenstein, Sergei M. 1949. Film Form: Essays in Film Theory. Jay Leyda, ed. and trans. New York: Harcourt Brace and Company.

- I988. Selected Works. Richard Taylor, ed. London: British Film Institute.

El-Kholy, Heba. 2002. Defiance and Compliance: Negotiating Gender in Low-Income Cairo. New York: Berghahn Books.

Elkins, James. 1996. The Object Stares Back: On the Nature of Seeing. New York: Simon \& Schuster.

Esposito, John L. 1998. Islam: The Straight Path. New York: Oxford University Press.

Evans-Pritchard, E. E. I956. Nuer Religion. Oxford: Clarendon Press.

- I965. Theories of Primitive Religion. Oxford: Oxford University Press.

. 1970. Some Reflections on Mysticism. DYN i: 99-II6.

—. 1976[1937]. Witchcraft, Oracles, and Magic among the Azande. Oxford: Clarendon Press.

Fabian, Johannes. 2002. Time and the Other: How Anthropology makes its Object. New York: Columbia University Press.

Fadil, Nadia. 20II. Not-/Unveiling as an Ethical Practice. Feminist Review 98(I): $83-109$.

Foucault, Michel. 1982. The Subject and Power. Critical Inquiry 8(4): 777-95. . I988[1961]. Madness and Civilization: A History of Insanity in the Age of Reason. New York:Vintage Books.

- 1997. On the Genealogy of Ethics: An Overview of Work in Progress. In Ethics: Subjectivity and Truth. Essential Works of Foucault, 1954-1984, Vol 1. Paul Rabinow, ed. Robert Hurley et al., trans. New York: New Press.

Fowler, W. W. 1920. The Original Meaning of the Word Sacer. In Roman Essays and Interpretations. Pp. I5-24. Oxford: Clarendon Press.

Fernando, Mayanthi L. 20I0. Reconfiguring Freedom: Muslim Piety and the Limits of Secular Law and Public Discourse in France. American Ethnologist 37(I): I9-35.

- 20I4. The Republic Unsettled: Muslim French and the Contradictions of Secularism. Durham, NC: Duke University Press.

Freud, Sigmund. 1959[1912]. The Dynamics of Transference. In Collected Papers of Sigmund Freud Volume 2. Joan Riviere, ed. and trans. Pp. 323-4I. New York: Basic Books.

- I980[1899]. The Interpretation of Dreams. New York: Avon.

- I989[1933]. New Introductory Lectures on Psycho-analysis. London: W. W. Norton \& Company.

-200I[1917]. Mourning and Melancholia. In The Standard Edition of the Complete Psychological Works of Sigmund Freud, Volume XIV (1914-1916). James Strachey et al., trans. Pp. 237-58. London: The Hogwarth Press. 
2003. Beyond the Pleasure Principle and Other Writings. John Reddick, trans. London: Penguin.

Friedson, Steven M. 1996. Dancing Prophets: Musical Experience in Tumbuka Healing. Chicago: University of Chicago Press.

Geertz, Clifford. 1993[1973]. The Interpretation of Cultures. London: Fontana Press.

Gomart, Emilie. 2002. Towards Generous Constraint: Freedom and Coercion in a French Addiction Treatment. Sociology of Health and Illness 24(5): 517-49.

Gormsen, Lise Kirstine. 2006. Autonomiens Problematisering: En Refleksion over Autonomibegrebet i en Psykiatrisk Forskningspraksis. Tidsskrift for Forskning i Sygdom og Samfund 4(4): II-3I.

Grimshaw, Anna and Amanda Ravetz. 2009. Rethinking Observational Cinema. Journal of the Royal Anthropological Institute I5: $538-56$.

Hacking, Ian. I999. The Social Production of What? Cambridge, MA: Harvard University Press.

Haraway, Donna J. 199r. Situated Knowledges: The Science Question in Feminism and the Privilege of Partial Perspective. In Simians, Cyborgs, and Women: The Reinvention of Nature. Pp. 183-202. New York: Routledge.

Harrington, Anne. 2000a. Introduction. In The Placebo Effect:An Interdisciplinary Exploration. Anne Harrington, ed. Pp. I-II. Cambridge, MA: Harvard University Press.

. 200ob. Placebo: Conversations at the Disciplinary Borders. In The Placebo Effect: An Interdisciplinary Exploration. Anne Harrington, ed. Pp. 208-50. Cambridge, MA: Harvard University Press.

Harrop, Chris. 2002. The Development of Schizophrenia in Late Adolescence. Current Psychiatry Reports 4(4): 293-8.

Harrop, Chris and Peter Trower. 2003. Why Does Schizophrenia Develop at Late Adolescence: A Cognitive-Developmental Approach to Psychosis. Chichester: Wiley.

Hastrup, Kirsten. 1992. Anthropological Visions: Some Notes on Visual and Textual Authority. In Film as Ethnography. Peter I. Crawford and David Turton, eds. Pp. 8-25. Manchester: Manchester University Press.

Healy, David. 1997. The Antidepressant Era. Cambridge, MA: Harvard University Press.

- 200I. Evidence Biased Psychiatry? Psychiatric Bulletin 25(8): 290-I.

- 2002. The Creation of Psychopharmacology. Cambridge, MA: Harvard University Press. . 2006. The New Medical Oikumene. In Global Pharmaceuticals: Ethics, Markets, Practices. Adriana Petryna, Andrew Lakoff, and Arthur Kleinman, eds. Pp. I-32. Durham, NC: Duke University Press.

Hegel, Georg Wilhelm Friedrich. 2003[1807]. The Phenomenology of Mind. New York: Dover Publications.

Helliwell, John, Richard Layard, and Jeffrey Sachs. 20I2. World Happiness Report 2012. New York: The Earth Insitute, Columbia University.

. 20I6. World Happiness Report 2016. New York: Sustainable Development Solutions Network.

- 2019. World Happiness Report 2019. New York: Sustainable Development Solutions Network.

Helweg-Larsen, Karin, Marianne Kastrup, Armando Baez, Esben M. Flachs. 2007. Etniske Forskelle i Kontaktmønsteret til Psykiatrisk Behandling: Et Registerbaseret Studie. Copenhagen: Videnscenter for Transkulturel Psykiatri. Retrieved March 28, 2013. www.si-folkesundhed.dk/upload/text-trykklar_samlet.pdf

Henare, Amiria, Martin Holbraad, and Sari Wastell. 2007. Introduction. In Thinking through Things: Theorising Artefacts Ethnographically. Amiria Henare, Martin Holbraad, and Sari Wastell, eds. Pp. I-3I. London: Routledge.

Henley, Paul. 2004. Putting Film to Work: Observational Cinema as Practical Ethnography. In Working Images:Visual Research and Representation in Ethnography. Sarah Pink, László Kürti, and Ana Isabel Afonso, eds. Pp. I09-30. London: Routledge.

- 2006. Spirit Possession, Power, and the Absent Presence of Islam: Re-viewing Les Maitres Fous. Journal of the Royal Anthropological Institute I2: 73I-6I. 
Hervik, Peter. 2004. The Danish Cultural World of Unbridgeable Differences. Ethnos 69(2): 247-67.

. 2006. The Predictable Responses to the Danish Cartoons. Global Media and Communication 2(2): 225-30.

- 20II. The Annoying Difference: The Emergence of Danish Neonationalism, Neoracism, and Populism in the Post-1989 World. New York and Oxford: Berghahn Books.

Herzfeld, Michael. 1992. The Social Production of Indifference. Chicago: University of Chicago Press.

Hirschkind, Charles. 2006. The Ethical Soundscape: Cassette Sermons and Islamic Counterpublics. New York: Columbia University Press.

- 20II. Is there a Secular Body? Cultural Anthropology 26(4): 633-47.

- 20I2. Experiments in Devotion Online:The Youtube Khuṭba. International Journal of Middle East Studies 44: 5-2I.

Højer, Lars and Andreas Bandak. 20I5. Introduction: The Power of Example. Journal of the Royal Anthropological Institute 2I(SI): I-I7.

Holbraad, Martin. 2007. The Power of Powder: Multiplicity and Motion in the Divinatory Cosmology of Cuban Ifá (or Mana, Again). In Thinking through Things: Theorising Artefacts Ethnographically. Amiria Henare, Martin Holbraad and Sari Wastell, eds. Pp. I89-225. London: Routledge.

. 20I2. Truth in Motion: The Recursive Anthropology of Cuban Divination. Chicago: Chicago University Press.

Holbraad, Martin and Rane Willerslev. 2007. Transcendental Perspectivism: Anonymous Viewpoints from Inner Asia. Inner Asia 9(2): 329-45.

Holenstein, Elmar. I999. The Zero-Point of Orientation: The Placement of the I in Perceived Space. In The Body. Donn Welton, ed. Pp. 57-94. Oxford: Blackwell Publishers.

Hopkins, Nicholas S. 2007. Spirit Mediumship in Upper Egypt. Anthropos I02(2): 403-I9.

Horner, Robyn. 2005. Jean-Luc Marion: A Theo-Logical Introduction. London: Ashgate Publishing Company.

Hubert, Henri and Marcel Mauss. 1964. Sacrifice: Its Nature and Function. W. D. Halls, trans. Chicago: The University of Chicago Press.

Huffington Post. 20I2. Mother Sara Ege Guilty of Murder of Son Yaseen, 7, Beaten to Death for not Learning Koran. Newspaper article. Retrieved II October 2018. www.huffingtonpost.co.uk/20I2/I2/05/koran-beaten-murder-ege-sara_n_2245077.html

Information. 2005. DFer: Sæt Muslimer i Russiske Fængsler. Newspaper article. Retrieved II October 20I8. www.information.dk/II3OI2

International Community for Hearing Voices. 20I2. What is Intervoice? Retrieved II October 2018. www.intervoiceonline.org/about-intervoice

Irving, Andrew. 20I3. Into the Gloaming: A Montage of the Senses. In Transcultural Montage. Christian Suhr and Rane Willerslev, eds. Pp. 76-95. New York: Berghahn.

- 20I7. The Art of Life and Death: Radical Aesthetics and Ethnographic Practice. Chicago: HAU Books.

Jacobsen, Brian Arly. 2007. Muslimer i Danmark: En Kritisk Vurdering af Antalsopgørelser. In Torre Tal om Troen: Religionsdemografi i det 21. Arhundrede. Margit Warburg og Brian Jacobsen, eds. Pp. I43-65. Højbjerg: Univers.

- 2008. Muslimer i Mandtal: Tal, Fordomme og Politik i Europa. Tidsskrift for Islamforskning 3(I): 84-IIO.

Jacobsen, Erling. 1984. De Psykiske Grundprocesser. Copenhagen: Centrum.

Jeldoft, Nadia. 20I3. The Hypervisibility of Islam. In Everyday Lived Islam in Europe. Nathal M. Dessing, Nadia Jeldoft, Jørgen S. Nielsen, and Linda Woodhead, eds. Pp. 28-38. Surrey: Ashgate.

Jensen, Pernille. 2006. En Helt Anden Hjalp: Recovery i Bruger- og Pårorendeperspektiv. Copenhagen: Akademisk Forlag.

Johansen, Christoffer and Niels Christian Hvidt, eds. 2003. Kan Tro Flytte Bjerge? Copenhagen: Gyldendal. 
Johansen, Katrine Schepelern. 2007. Kategorisering i Psykiatrien: Patienter med Anden Etnisk Baggrund end Dansk. In Intregration: Antropologiske Perspektiver. Karen Fog Olwig and Karsten Pærregaard, eds. Pp. I55-7I. Copenhagen: Museum Tusculanums Forlag.

Johansen, Mette-Louise and Steffen Jensen. 20I7. They want us out: Urban Regeneration and the Limits of Integration in the Danish Welfare State. Critique of Anthropology 37(3): 297-3I6.

Jyllandsposten. 20II. Islamisk Gruppe Vækker Afsky. Newspaper article. Retrieved 28 March 20I3. http://jyllands-posten.dk/indland/article2578564.ece

Kapferer, Bruce. 20I3. Montage and Time: Deleuze, Cinema and a Buddhist Sorcery Rite. In Transcultural Montage. Christian Suhr and Rane Willerslev, eds. Pp 20-39. New York: Berghahn.

- 20I4. 2001 and Counting: Kubrick, Nietzsche, and Anthropology. Chicago: Prickly Paradigm Press.

Karlsson, Bengt. 2009. Pasienterfaringer som Kunnskapsgrunnlag i Psykiatrisk Sykepleie. In Psykiatrisk Sygepleje. Niels Buus, ed. Copenhagen: Dansk Sygeplejeråd og Nyt Nordisk Forlag Arnold Busck.

Kassim, Husain. I97I. Existentialist tendencies in Ghazali and Kierkegaard. Islamic Studies IO: IO3-28.

Kaufmann, Walter. 1965. Hegel: A Reinterpretation. New York: Doubleday.

Keane, Webb. 2009. Freedom and Blasphemy: On Indonesian Press Bans and Danish Cartoons. Public Culture 2I(I): 47-76.

- 2013. On Spirit Writing: Materialities of Language and the Religious Work of Transduction. Journal of the Royal Anthropological Institute I9(I): I-I7.

Kelly, Sean D. 2005. Seeing Things in Merleau-Ponty. In The Cambridge Companion to Merleau-Ponty. Taylor Carman and Mark B. N. Hansen, eds. Pp. 74-IIo. Cambridge: Cambridge University Press.

Kessler, Edward. 2004. Bound by the Bible: Jews, Christians and the Sacrifice of Isaac. Cambridge: Cambridge University Press.

Khan, Naveeda. 2006. Of Children and Jinn: An Inquiry into an Unexpected Friendship During Uncertain Times. Cultural Anthropology 2I (2): 234-64.

Kiener, Wilma. 2008. The Absent and the Cut. Visual Anthropology 21: 393-409.

Kierkegaard, Søren. 2005[1843]. Fear and Trembling. Alastair Hannay, trans. London: Penguin.

Kiev, Ari. 1962.The Psychotherapeutic Aspects of Primitive Medicine. Human Organization 2I (I): 25-9.

Kirsch, Irving. 2000. Specifying Non-Specifics: Psychological Mechanisms of Placebo Effects. In The Placebo Effect:An Interdisciplinary Exploration. Anne Harrington, ed. Pp. I66-86. Cambridge, MA: Harvard University Press.

- 20Io. The Emperor's New Drugs: Exploding the Antidepressant Myth. New York: Basic Books.

Kleinman, Arthur. 1980. Patients and Healers in the Context of Culture: An Exploration of the Borderland between Anthropology, Medicine, and Psychiatry. Berkeley: University of California Press.

- I988. The Illness Narratives: Suffering, Healing, and the Human Condition. New York: Basic Books.

- 20I2. Culture, Bereavement, and Psychiatry. The Lancet 379(98I6): 608-9.

Klitgaard, Ann-Charlotte. 2009. Recovery: Psykiatrien har brug for nye historier. Bedre Psykiatri 2: 7-9.

Köhn, Steffen. 20I6. Mediating Mobility: Visual Anthropology in the Age of Migration. New York: Wallflower Press.

Kreinath, Jens. 20I2. Comment on the Article 'Can Film Show the Invisible: The Work of Montage in Ethnographic Filmmaking'. Current Anthropology 53(3): 296-7.

Kühle, Lene. 2006. Moskeer i Danmark: Islam og Muslimske Bedesteder. Højbjerg: Forlaget Univers. 
Larsen, Birgitte Romme. 20II. Drawing back the Curtains: The Role of Domestic Space in the Social Inclusion and Exclusion of Refugees in Rural Denmark. Social Analysis 55(2): 142-58.

Larsen, Timothy. 20I4. The Slain God: Anthropologists and the Christian Faith. Oxford: Oxford University Press.

Latour, Bruno. 1993. We Have Never Been Modern. Catherine Potter, trans. Cambridge, MA: Harvard University Press.

- 2002. What is Iconoclash? Or is there a World beyond the Image Wars. In Iconoclash: Beyond the Image Wars in Science, Religion, and Art. Bruno Latour and Peter Weibel, eds. Pp. I4-37. Cambridge, MA: MIT Press.

. 2004. Why has Critique Run Out of Steam? From Matters of Fact to Matters of Concern. Critical Inquiry 30(2): 225-48.

Lauritsen, Peter. 20II. Big Brother 2.o: Danmark som Overvågningssamfund. Copenhagen: Informations Forlag.

Lehmann, Arthur C. and James E. Myers. 1993. The Anthropological Study of Religion: Introduction. In Magic, Witchcraft, and Religion: An Anthropological Study of the Supernatural. Arthur C. Lehmann and James E. Myers, eds. Pp. I-5. Mountain View: Mayfield Publishing Company.

Levinas, Emmanuel. I979[1961]. Totality and Infinity: An Essay on Exteriority. Alphonso Lingis, trans. The Hague: Martinus Nijhoff Publishers.

- 1985. Ethics and Infinity: Conversations with Philippe Nemo. Richard A. Cohen, trans. Pittsburgh: Duquesne University Press.

- I987a. Time and the Other and Additional Essays. Richard A. Cohen, trans. Pittsburgh: Duquesne University Press.

- I987b. Collected Philosophical Papers. Alphonso Lingis, trans. Dordrecht: Martinus Nijhoff Publishers.

Levine, Bruce. 2004. Eli Lilly, Zyprexa, and the Bush Family: The Diseasing of our Malaise. Z Magazine I7(5). Retrieved 8 March 20I3. http://psychrights.org/articles/ LevineLillyandBush.htm

Lévi-Strauss, Claude. I983[1964]. The Raw and the Cooked: Mythologiques. Vol. 1. John and Doreen Weightman, trans. Chicago: University of Chicago Press.

- 1993[1963]. The Sorcerer and His Magic. In Magic, Witchcraft, and Religion: An Anthropological Study of the Supernatural. Arthur C. Lehmann and James E. Myers, eds. Pp. I69-78. Mountain View: Mayfield Publishing Company.

. 200I[1978]. Myth and Meaning, London: Routledge.

Lindekilde, Lasse. 20I0. Forebyggelse af Radikalisering, Miskendelse og Muslimsk Minoritetsidentitet. Tidsskrift for Islamforskning 20IO(2): 7-29.

Lovat, Terry and Inna Semetsky. 2009. Practical Mysticism and Deleuze's Ontology of the Virtual. Cosmos and History: The Journal of Natural and Social Philosophy 5(2): 236-49.

Luhrmann, Tanya. 2000. Of Two Minds: The Growing Disorder in American Psychiatry. New York: Vintage Books.

- 20I2a. Living with Voices: A New Way to Deal with Disturbing Voices Offers Hope for Those with Other Forms of Psychosis. The American Scholar 8I (3): 48. Retrieved 20 November 20I6. https://theamericanscholar.org/living-with-voices/\#.WhLu-rbMzMU

- 20I2b. When God Talks Back: Understanding the American Evangelical Relationship with God. New York: Alfred Knopf.

- 2016. Understanding the Work of Faith. In Faith in Anthropology: A Symposium on Timothy Larsen's The Slain God. Brian Howell, et al. The Cambridge Journal of Anthropology 34(2): 147-9.

Maarouf. Mohammed. 2007. Jinn Eviction as a Discourse of Power: A Multidisciplinary Approach to Moroccan Magical Beliefs and Practices. Leiden: Brill Academic Publishers. MacDougall, David. 1998. Transcultural Cinema. Princeton: Princeton University Press.

. 2006. The Corporeal Image: Film, Ethnography, and the Senses. Princeton: Princeton University Press.

Mahmood, Saba. 2005. Politics of Piety: The Islamic Revival and the Feminist Subject. Princeton: Princeton University Press. 
2009. Religious Reason and Secular Affect: An Incommensurable Divide? Critical Inquiry 35(4): 836-62.

Malinowski, Bronislaw. 2004[1948]. Magic, Science and Religion and Other Essays. With introduction by Robert Redfield. Whitefish, MT: Kessinger Publishing.

Marcus, George E. 1994. The Modernist Sensibility in Recent Ethnographic Writing and the Cinematic Metaphor of Montage. In Visualizing Theory: Selected Essays from V.A.R. 1990-1994. Lucien Taylor, ed. Pp. 37-53. New York: Routledge.

- I998. The Uses of Complicity in the Changing Mise-en-Scène of Anthropological Fieldwork. In Ethnography through Thick and Thin. Pp. I05-32. Princeton: Princeton University Press.

- 2013. Afterword:The Traffic in Montage, Then and Now. In Transcultural Montage. Christian Suhr and Rane Willerslev, eds. Pp. 302-7. New York: Berghahn.

Marion, Jean-Luc. 2002. In Excess: Studies of Saturated Phenomena. Robyn Horner and Vincent Berraud, trans. New York: Fordham University Press.

Marks, Laura U. 2000. The Skin of the Film: Intercultural Cinema, Embodiment, and the Senses. London: Duke University Press.

- 20Io. Enfoldment and Infinity:An Islamic Genealogy of New Media Art. Cambridge, MA: Massachusetts Institute of Technology.

Marx, Karl. 1975[I844]. Introduction: A Contribution to the Critique of Hegel's Philosophy of the Right. In Early Writings. Pp. 244-57. Harmondsworth: Penguin Books.

Marx, Karl and Frederich Engels. 1988[1844]. Economic and Philosophical Manuscripts of 1844 and the Communist Manifesto. Martin Milligan, trans. New York: Prometheus Books.

Mattingly, Cheryl. 1998. Healing Dramas and Clinical Plots: The Narrative Structure of Experience. Cambridge: Cambridge University Press.

. 20I0. Moral Willing as Narrative Re-Envisioning. In Toward an Anthropology of the Will. Keith Murphy and Jason Throop, eds. Pp. 50-69. Stanford: Stanford University Press.

- 2012. Two Virtue Ethics and the Anthropology of Morality. Anthropological Theory I2(2): I6I-84.

McGlashan, T., R. Zipusky, D. Perkins, J. Addington, T. Miller, S. Woods, K. Hawkins, R. Hoffman, A. Preda, I. Epstein, D. Addington, S. Lindborg, Q. Trzaskoma, M. Tohen, and A. Breier. 2006. Randomized, Double-Blind Trial of Olanzapine Versus Placebo in Patients Prodromally Symptomatic for Psychosis. American Journal of Psychiatry I63(5): 790-9.

Mead, Margaret and Gregory Bateson. 1977. On the Use of the Camera in Anthropology. Studies in the Anthropology of Visual Communication 4(2): 78-80.

Merleau-Ponty, Maurice. I964[1948]. Sense and Nonsense. Hubert L. Dreyfus and Patricia Allen Dreyfus, trans. Evanston, IL: Northwestern University Press.

I976. Philosophy and Non-Philosophy since Hegel. Telos 29: 43-I05.

. I988. In Praise of Philosophy and Other Essays. Evanston, IL: Northwestern University Press.

- 1997[1964]. The Visible and the Invisible: Followed by Working Notes. Alphonso Lingis, trans. Evanston: Northwestern University Press.

- 2000. Eye and Mind. In The Primacy of Perception: And Other Essays on Phenomenological Psychology, the Philosophy of Art, History and Politics. James M. Edie, ed. William Cobb, trans. Pp. I59-90. Evanston: Northwestern University Press.

- 2002[1945]. Phenomenology of Perception. Colin Smith, trans. New York: Routledge.

Metcalf, Peter. 2002. They Lie, We Lie: Getting on with Anthropology. London: Routledge.

Ministries of the Interior, Health, and Social Affairs. 2005. Respekt, Faglighed, Ansvar: Fælles Værdier i Indsatsen for Mennesker med en Sindslidelse. Policy paper. Retrieved I4 April 20I9. www.sum.dk/Aktuelt/Publikationer/Faelles-vaedier-i-indsatsen-for-mennekser -med-en-sindslidelse-dec-2005.aspx

Ministry of Social Affairs. 20II. Liste over ghettoområder pr. 1. januar 2011. Policy Paper. Retrieved 28 March 20I3. www.sm.dk/data/Dokumentertilnyheder/20II/ghettoomr\% C3\%A5der_pr_I_januar.pdf 
Ministry of Transport, Building, and Housing. 20I6. Liste over ghettoområder pr. 1. december 2016. Policy paper. Retrieved 7 November 20I7. www.trm.dk/da/publikationer/20I6/ liste-over-ghettoomraader

Mittermaier, Amira. 20II. Dreams that Matter: Egyptian Landscapes of the Imagination. Berkeley: University of California Press.

Nathan, Tobie and Isabelle Stengers. 20I8. Doctors and Healers. Cambridge, UK: Polity Press.

Nielsen, Maria Rebecca, Anne Marie Mikkelsen, and Jørgen Aagaard. 2009. Styr på Stemmerne: Gruppetilbud til Stemmehorere. Aarhus: Center for Psykiatrisk Forskning, Janssen-Cilag.

Norredam, Marie, A. Garcia Lopez, N. Keiding, and A. Krasnik. 2009. Risk of Mental Disorders in Refugees and Native Danes: A Register-Based Retrospective Cohort Study. Social Psychiatry and Psychiatric Epidemiology 44: 1023-9.

OED. 2019. Oxford English Dictionary Online. Oxford: Oxford University Press. Retrieved Is January 20I9. www.oed.com

Ohnuma, Reiko. 2007. Head, Eyes, Flesh, and Blood: Giving Away the Body in Indian Buddhist Literature. New York: Columbia University Press.

OPUS. 2007. Opsøgende Behandling af Psykotiske Unge. Retrieved II October 2018. https://viden.sl.dk/media/5888/opus-danske-regioern.pdf

Ortner, Sherry B. 1984. Theory in Anthropology since the Sixties. Comparative Studies in Society and History 26(I): I26-66.

-2006. Anthropology and Social Theory: Culture, Power, and the Acting Subject. Durham, NC: Duke University Press.

Otto, Ton. 1997. Informed Participation and Participating Informants. Canberra Anthropology 20(I-2): 96-I08.

Otto, Ton and Poul Pedersen. 2005. Disentangling Traditions: Culture, Agency and Power. In Tradition and Agency. Tracing Cultural Continuity and Invention. Ton Otto and Poul Pedersen, eds. Pp. II-49. Aarhus: Aarhus University Press.

Pandolfo, Stefania. I997. Impasse of the Angels: Scenes from a Moroccan Space of Memory. Chicago: University of Chicago Press.

- 2007. The Burning: Finitude and the Politico-Theological Imagination of Illegal Migration. Anthropological Theory 7(3): 329-63.

- 20II. Clad in Mourning:Violence, Subjugation and the Struggle of the Soul. In Review of Women Studies. Pp. 25-39. Excerpt from keynote address held at the IWS Conference, Birzeit University, March 2010.

- 20I8. Knot of the Soul: Madness, Psychiatry, Islam. Chicago: University of Chicago Press.

Parker, Gordon, Ian M. Anderson, and Peter Haddad. 2003. Clinical Trials of Antidepressant Medications are Producing Meaningless Results. The British Journal of Psychiatry I83(2): IO2-4.

Pattison, E. Mansell. 1977. Psychosocial Interpretations of Exorcism. Journal of Operational Psychiatry 8(2): 5-2I.

Pedersen, Morten Axel. 20II. Not Quite Shamans: Spirit Worlds and Political Lives in Northern Mongolia. Ithaca, NY: Cornell University Press.

Pelkmans, Mathijs, ed. 20I3. Ethnographies of Doubt: Faith and Uncertainty in Contemporary Societies. New York: I. B. Tauris.

Petersen, Lone, Merete Nordentoft, Pia Jeppesen, Johan Øhlenschlæger, Anne Thorup, Torben Østergaard Christensen, Gertrud Krarup, Jytte Dahlstrøm, Bodil Haastrup, and Per Jørgensen. 2005. Improving I-Year Outcome in First-Episode Psychosis: OPUS Trial. The British Journal of Psychiatry I87: 98-103.

Petryna, Adriana and Arthur Kleinman. 2006. The Pharmaceutical Nexus. In Global Pharmaceuticals: Ethics, Markets, Practices. Adriana Petryna, Andrew Lakoff, and Arthur Kleinman, eds. Pp. I-32. Durham, NC: Duke University Press.

Philips, Bilal. 2007. The Exorcist Tradition in Islam. Birmingham: Al-Hidaayah Publishing. Politiken. 20I2. Marie Krarup:Vi er i krig med den islamiske civilization [Marie Krarup: We are at War with the Islamic Civilisation]. Newspaper article. Retrieved I5 January 
20I9. https://politiken.dk/indland/politik/art542343I/Marie-Krarup-Vi-er-i-krigmed-den-islamiske-civilisation

- 20I3. Jobopslag: Folkekirke søger præst som tror på Gud [Church Seeks Priest who Believes in God]. Newspaper article. Retrieved 28 March 20I3. http:// politiken.dk/indland/ECEI874334/jobopslag-folkekirke-soeger-praest-som-tror-paagud/

Quist, Pia. 2000. Ny Københavnsk 'Multietnolekt'. Danske Talesprog I: I43-2 II.

Rabinow, Paul. 1996. Making PCR: A Story of Biotechnology. Chicago: University of Chicago Press.

Rasmussen, Klavs Serup. 2006. Psykiatribrugere må acceptere at få sukkersyge. Outsideren 58: I8-I9. Retrieved 8 March 2013. www.outsideren.dk/wp-content/ uploads/2009/12/2006_nummer58.pdf\#page=I8

Ray, Wayne A., Cecilia P. Chung, Katherine T. Murray, Kathi Hall, and C. Michael Stein. 2009. Atypical Antipsychotic Drugs and the Risk of Sudden Cardiac Death. New England Journal of Medicine 360(3): 225-35.

Region Midtjylland. 2009. Politik for Samarbejde mellem Psykisk Syge, Pårørende og Personale i Behandlings-og Socialpsykiatrien. Policy paper. Retrieved 4 March 20I3. www.regionmidtjylland.dk/politik/regionsrådets+møder/visdagsorden?file=2904-2009/Aaben_dagsorden/Bilag/Punkt_6_Bilag_2 .PDF

Ringgaard, Anne. 20I2. Ingen gider forske $\mathrm{i}$ indvandreres sundhed. Interview with Allan Krasnik. Videnskab.dk. Retrieved 28 March 20I3. http://videnskab.dk/krop-sundhed/ ingen-gider-forske-i-indvandreres-sundhed

Robbins, Joel. 20I5. Ritual,Value, and Example: On the Perfection of Cultural Representations. Journal of the Royal Anthropological Institute $2 \mathrm{I}\left(\mathrm{S}_{\mathrm{I}}\right)$ : I8-29.

Roberts, Graham. 2000. The Man with the Movie Camera. London: I. B. Tauris.

Romme, Marius and Sandra Escher. 2000. Making Sense of Voices: A Guide for Mental Health Professionals Working with Voice-Hearers. London: Mind Publications.

Rorty, Richard. I991a. Consequences of Pragmatism. New York: Harvester Wheatsheaf.

-. I99rb. Objectivity, Relativism and Truth. Cambridge: Cambridge University Press.

Rose, Nikolas. 2003. Neurochemical Selves. Society 4I(I): 46-59.

- 2018. Our Psychiatric Future: The Politics of Mental Health. Cambridge: Polity.

Rothenberg, Celia. 2004. Spirits of Palestine: Gender, Society and Stories of the Jinn. Maryland: Lexington Press.

Rothman, William. 1997. Documentary Film Classics. Cambridge: Cambridge University Press.

Rouch, Jean. 2003. The Camera and Man. In Principles of Visual Anthropology. Paul Hockings, ed. Pp. 79-98. NewYork: Mouton de Gruyter.

Russell, Catherine. I999. Experimental Ethnography: The Work of Film in the Age of Video. Durham, NC, and London: Duke University Press.

Rytter, Mikkel. 20Ioa. The Family of Denmark and the Aliens: Kinship Images in Danish Integration Politics. Ethnos 75(3): 30I-22.

- 20Iob. In-laws and Outlaws: Black Magic among Pakistani Migrants in Denmark. Journal of the Royal Anthropological Institute I6(I): 46-63.

- 20I8. Writing against Integration: Danish Imaginaries of Culture, Race and Belonging. Ethnos, DOI: I0.1080/ooI4I844.20I8.I458745.

Rytter, Mikkel and Marianne Pedersen. 20I4. A Decade of Suspicion: Islam and Muslims in Denmark after 9/II. Ethnic and Racial Studies 37(13): 2303-2I.

Said, Edward W. I995. Orientalism: Western Conceptions of the Orient. London: Penguin.

Safer, Daniel J. 2002. Design and Reporting Modifications in Industry-Sponsored Comparative Psychopharmacology Trials. The Journal of Nervous and Mental Disease I90(9): 583-92.

Samvirket i Gellerup og Toveshøj. 20I6. Fakta og Tal. Retrieved I7 September 2017. http://samvirket.dk/fakta

Sartre, Jean Paul 2000[1943]. Being and Nothingness: An Essay on Phenomenological Ontology. Hazel E. Barnes, trans. Oxon: Routledge. 
Schäuble, Michaela. 2or6a. Mining Imagination: Ethnographic Approaches Beyond the Written Word. Anthrovision 4(2): I-II.

- 20I6b. Images of Ecstasy and Affliction:The Camera as Instrument for Researching and Reproducing Choreographies of Deviance in a Southern Italian Spider Possession Cult. Anthrovision 4(2): I-28.

Schielke, Samuli. 20Io. Second Thoughts about the Anthropology of Islam, or How to Make Sense of Grand Schemes in Everyday Life. Berlin: Zentrum Moderner Orient Working Papers.

- 2019. The Power of God: Four Proposals for an Anthropological Engagement. ZMO Programmatic Texts I3, Pp. I-20. Berlin: Leibniz-Zentrum Moderner Orient (ZMO).

Schilbrack, Kevin. 2005. Religion, Models of, and Reality: Are we Through with Geertz? Journal of the American Academy of Religion 73: 429-52.

Schmidt, Anders Legarth. 20I3. Endnu En Patient Dør På Lukket Psykiatrisk Afdeling. Newspaper article. Politiken. Retrieved II October 20I8. http://politiken.dk/indland/ ECEI9I4909/endnu-en-patient-doer-paa-lukket-psykiatrisk-afdeling/

Schmidt, Garbi, Birgitte Schepelern Johansen, and Dorthe Høvids Possing. 2008. Foreword. In Research on Islam Repositioned: New Agendas in the Study of Islam and Muslims in a Politicised Research Field. Special issue of Tidsskrift for Islamforskning 2: 3-4.

Schwartz, Louis-Georges. 2005. Typewriter: Free Indirect Discourse in Deleuze's Cinema. SubStance 34(3): 107-35.

Scott, James C. I990. Domination and the Arts of Resistance: Hidden Transcripts. New Haven: Yale University Press.

- I998. Seeing like a State: How Certain Schemes to Improve the Human Condition have Failed. New Haven:Yale University Press.

Sedgwick, Mark. 2006. Islam and Muslims: A Guide to Diverse Experience in a Modern World. Boston: Intercultural Press.

- 20I0. Contextualizing Salafism. Tidskrift for Islamforskning I: 75-8I.

. 20I4. Introduction: Families, Governments, Schools, Alternatice Spaces and the Making of European Muslims. In Making European Muslims: Religious Socialization and the Formation of Identities among Muslim Children and Young Muslims in Western Europe. Mark Sedgwick, ed. Pp. I-20. London: Routledge.

- 2016. Western Sufism: From the Abbasids to the New Age. Oxford: Oxford University Press.

Severi, Carlo. 2002. Memory, Reflexivity and Belief: Reflections on the Ritual Use of Language. Social Anthropology IO(I): 23-40.

Shariati, Ali. I979. On the Sociology of Islam: Lectures by Ali Shariati. Hamid Algar, trans. New York: Mizan Press.

Simonsen, Erik. 20I2. Den Etiske Fordring i Psykiatrien. Newspaper article. Politiken. Retrieved II October 20I8. http://politiken.dk/debat/kroniken/ECEI807I37/ den-etiske-fordring-i-psykiatrien/

Sjørslev, Inger. 2002. Forestillinger om Folket. In Folkets Reprasentanter: Et Antropologisk Blik på Folketinget. Finn Sivert Nielsen and Inger Sjørslev, eds. Pp. 9-34. Aarhus: Aarhus Universitetsforlag.

Skovgaard-Petersen, Jakob. 20I6. Der er forskel på had-, svovl- og reformprædikanter. Online opinion article. Danmarks Radio. Retrieved II October 20I8. www.dr.dk/ nyheder/kultur/tro/islamforsker-der-er-forskel-paa-had-svovl-og-reformpraedikanter

Slater, Tom. 20Io. Ghetto Blasting: On Loïc Wacquant's Urban Outcasts. Urban Geography 3I(2): I62-8.

Sobchack, Vivian. 1992. The Address of the Eye: A Phenomenology of Film Experience. Princeton: Princeton University Press.

Spiro, Melford E. I966. Religion: Problems of Definition and Explanation. In Anthropological Approaches to the Study of Religion. Michael Banton, ed. Pp. 85-I26. London:Tavistock Publications.

Stage, Carsten. 20II. Tegningekrisen: Som Mediebegivenhed og Danskhedskamp. Aarhus: Aarhus Universitetsforlag. 
Steinbock, Anthony J. 2007. Phenomenology and Mysticism: The Verticality of Religious Experience. Bloomington, IN: Indiana University Press.

Stoller, Paul. I984. Eye, Mind and Word in Anthropology. L'Homme 24: 9I-II4.

Suhr, Christian. 20I4. Brainwashed at School: Deprogramming the Secular among Young Neo-Orthodox Muslims in Denmark. In Making European Muslims: Religious Socialization Among Young Muslims in Scandinavia and Western Europe. Mark Sedgwick, ed. Pp. 249-68. London: Routledge.

- 20I5. The Failed Image and the Possessed: Examples of Invisibility in Visual Anthropology and Islam. Journal of the Royal Anthropological Society 2I(I): 96-II2.

- 20I6. Livet i moskeerne er langt mere, end hvad vi ser i TV [Life in the Mosques is More Than we See on TV]. Opinion article. Politiken. Retrieved II October 20I8. https://politiken.dk/debat/kroniken/art56I4897/Livet-i-moskeerneer-langt-mere-end-hvad-vi-ser-i-tv

- 2017. Islamic Exorcism and the Cinema Fist:Analyzing Exorcism among Danish Muslims through the Prism of Film. Contemporary Islam. https://doi.org/I0. I007/ SII562-OI7-0394-6

- 20I8. Camera Monologue: Cultural Critique beyond Collaboration, Participation and Dialogue. Journal of Visual Anthropology 31: 376-93.

Suhr, Christian and Kirstine Sinclair. 20I6. Fakta og Fiktion om muslimer i danske medier [Facts and Fictions about Danish Muslims in Danish Media]. Tidsskrift for Islamforskning IO(I): $134-48$.

Suhr, Christian and Rane Willerslev. 20I2. Can Film Show the Invisible: The Work of Montage in Ethnographic Filmmaking. Current Anthropology 53(3): 282-30I.

_. 2013. Transcultural Montage. New York: Berghahn.

Suhr, Christian, Hjarn von Zernichow Borberg, Kirstine Sinclair, and Niels Valdemar Vinding. 20I7. Cavling-nomineret tv-dokumentar er unuanceret og menings forvridende [Cavling-nominated TV Documentary is One-sided and Misleading]. Opinion article. Politiken. Retrieved II October 20I8. https://politiken.dk/debat/kroniken/ art577I535/Cavling-nomineret-dokumentar-er-unuanceret-og-meningsforvridende

Tambiah, Stanley Jeyaraya. 1990. Magic, Science, Religion, and the Scope of Rationality. Cambridge: Cambridge University Press.

Tamen, Miguel. 200I. Friends of Interpretable Objects. Massachusetts, MA: Harvard University Press.

Taneja, Anand Vivek. 20I7. Jinnealogy: Time, Islam, and Ecological Thought in the Medieval Ruins of Delhi. Stanford, CA: Stanford University Press.

Taussig, Michael. 1980. The Devil and Commodity Fetishism in South America. Chapel Hill: University of North Carolina Press.

- I986. Shamanism, Colonialism, and the Wild Man: A Study in Terror and Healing. Chicago: University of Chicago Press.

- I993. Mimesis and Alterity: A Particular History of the Senses. London: Routledge. . I999. Defacement: Public Secrecy and the Labor of the Negative. Stanford: Stanford University Press.

Taylor, Charles. I990. Philosophy and the Human Sciences: Philosophical Papers 2. Cambridge: Cambridge University Press.

Taymiyah, S. I. I. 2007[1263-I328 C.E.]. Essay on the Jinn. Bilal Philips, ed. and trans. Riyadh: International Islamic Publishing House.

Thorup, A., L. Petersen, P. Jeppesen, J. Øhlenschlæger, T. Christensen, G. Krarup, P. Jørgensen, and M. Nordentoft. 2005. Integrated Treatment Ameliorates Negative Symptoms in First Episode Psychosis: Results from the Danish Opus Trial. Schizophrenia Research 79: 95-105.

Tiihonen, Jari, Jouko Lönnqvist, Kristian Wahlbeck, Timo Klaukka, Antti Tanskanen, and Jari Haukka. 2006. Antidepressants and the Risk of Suicide, Attempted Suicide, and Overall Mortality in a Nationwide Cohort. Archives of General Psychiatry 63(I2): I358-67.

Tomlinson, Matt. 20I4. Bringing Kierkegaard into Anthropology: Repetition, Absurdity, and Curses in Fiji. American Ethnologist 4I: I63-75. 
Transparency International. 20I6. Corruption Perceptions Index 2016. Berlin: Transparency International.

Trinh, T. Minh-Ha. I99. When the Moon Waxes Red: Representation, Gender and Cultural Politics. New York: Routledge.

Turner, Edith. 1989. From Shamans to Healers:The Survival of an Inupiaq Eskimo Skill. Anthropologica 3I(I): 3-24.

- I992. Experiencing Ritual: A New Interpretation of African Healing. Philadelphia: University of Pennsylvania Press.

- I993. The Reality of Spirits: A Tabooed or Permitted Field of Study. Anthropology of Consciousness 4(I): 9-I2.

. 2006. Advances in the Study of Spirit Experience: Drawing Together Many Threads. Anthropology of Consciousness I7(2): 33-6I.

Turner, Erick H., Daniel Knoepflmacher, and Lee Shapley. 20I2. Publication Bias in Antipsychotic Trials: An Analysis of Efficacy comparing the Published Literature to the US Food and Drug Administration Database. PLOS Medicine 9(3): I-I7.

Turner, Victor. 1967. The Forest of Symbols: Aspects of Ndembu Ritual. Ithaca: Cornell University Press.

US Department of Justice. 2009. Eli Lilly and Company Agrees to Pay \$I.4IS Billon to Resolve Allegations of Off-label Promotion of Zyprexa. Retrieved 8 March 2013. www.justice.gov/opa/pr/2009/January/o9-civ-038.html

Vacher, Mark. 20Io. Looking at Houses, Searching for Homes: An Anthropological Analysis of the Relationship between Danish Homeowners and their Houses. Ethnologia Scandinavica 40: 52-67.

van Beek, Martijn. 20I2. Enlightened Democracy: Normative Secularism and Spiritual Authority on the Margins of Indian Politics. In Varieties of Secularism in Asia:Anthropological Explorations of Religion, Politics and the Spiritual. Nils Bubandt and Martijn van Beek, eds. Pp. 75-I00. London: Routledge.

van der Geest, Sjaak. 2005. 'Sacraments' in the Hospital: Exploring the Magic and Religion of Recovery. Anthropology and Medicine I2(2): I35-50.

Vaughan, Dai. 1992. The Aesthetics of Ambiguity. In Film as Ethnography. Peter I. Crawford and David Turton, eds. Pp. 99-II5. Manchester: Manchester University Press.

Vertov, Dziga. 1984. Kinoks: A Revolution. In Kino-Eye: The Writings of Dziga Vertov. Annette Michelson, ed. Pp. II-20. Berkeley: University of California Press.

Videnscenter for Transkulturel Psykiatri. 20I2. Transkulturelle Patienter. Retrieved 28 March 20I3. www.vftp.dk/temaer/fakta\%20og\%20tal/transkulturelle_patienter.html

Vigh, Henrik and Simon Turner. 2007. Indledning: Usynlighed. Den Ny Verden Tidsskrift for International Studier 4O(2): 7-I4.

Vinding, Niels Valdemar. 20I6. The Question of Sharī'a in Denmark. Blog. Cambridge: Harvard Law School. Retrieved 7 November 20I7. https://shariasource.blog/2016/08/03/ 264/

Viveiros de Castro, Eduardo. 20Ir. Zeno and the Art of Anthropology: Of Lies, Beliefs, Paradoxes, and Other Truths. Common Knowledge I7(I): 128-45.

Wacquant, Loïc. 2008. Ghettos and Anti-Ghettos: An Anatomy of the New Urban Poverty. Thesis Eleven 94(I): II3-I8.

Wahhab, S. I. M. Abdul. I996[1703-I792 C.E.]. The Book of Monotheism. Riyadh: Darussalam.

Waltorp, Karen. 20I8. Intimacy, Concealment and Unconscious Optics: Filmmaking with Young Muslim Women in Copenhagen. Journal of Visual Anthropology 31: 394-407.

Weiner, James. I997. Televisualist Anthropology: Representation, Aesthetics, Politics. Current Anthropology 38: 197-235.

White, Adrian. 2006. University of Leicester Produces the First-ever World Map of Happiness. Press release. Leicester: University of Leicester. Retrieved 28 March 20I3. www2. le.ac.uk/ebulletin/news/press-releases/2000-2009/2006/07/nparticle.2006-07-28 .2448323827 
Whyte, Susan Reynolds. I997. Questioning Misfortune: The Pragmatics of Uncertainty in Eastern Uganda. Cambridge: Cambridge University Press.

Wikan, Unni. 1991. Behind the Veil in Arabia: Women in Oman. Chicago: University of Chicago Press.

Willerslev, Rane. 2007. Soul Hunters: Hunting, Animism and Personhood among the Siberian Yukaghirs. Berkeley: University of California Press.

- 2009a. To have the World at a Distance: Reconsidering the Significance of Vision for Social Anthropology. In Skilled Visions: Between Apprenticeship and Standards. Cristina Grassini, ed. Pp. 23-46. London: Berghahn.

- 2009b. The Optimal Sacrifice: A Study of Voluntary Death among the Siberian Chukchi. American Ethnologist 36(4): 693-704.

- 2013a. Taking Animism Seriously, but Perhaps not too Seriously? Religion and Society 4(I): 4I-57.

- 20I3b. God on Trial: Human Sacrifice, Trickery and Faith. HAU: Journal of Ethnographic Theory 3(I): I40-54.

Willerslev, Rane and Christian Suhr. 20I8. Is There a Place for Faith in Anthropology? Religion, Reason, and the Ethnographer's Divine Revelation. HAU: Journal of Ethnographic Theory 8(I-2): 65-78.

Willerslev, Rane and Morten Axel Pedersen. 20Io. Joking the Cosmos into the Right Shape in North Asia. In Experiments in Holism: Theory and Practice in Contemporary Anthropology. Ton Otto and Nils Bubandt, eds. Pp. 262-78. West Sussex:Wiley-Blackwell.

Wyschogrod, Edith. 2002. Language and Alterity in the Thought of Levinas. In The Cambridge Companion to Levinas. Simon Critchley and Robert Bernasconi, eds. Pp. I88-205. Cambridge: Cambridge University Press.

Young, Allan. 20Ir. Self, Brain, Microbe, and the Vanishing Commissar. Science, Technology, and Human Values 36(5): 638-6I.

Zola, Irving Kenneth. 1973. Pathways to the Doctor: From Person to Patient. Social Science and Medicine 7(9): 677-89.

Zuckerman, Phil. 2008. Society without God: What the Least Religious Nations Can Tell us about Contentment. New York: New York University Press.

\section{FILMS AND MEDIA}

Aaltonen, Jouko. 20oI. Kusum. 69 min. Helsinki: ILLUME.

Al-Awlaki, Anwar. 20IO. The Hereafter. Collection of 22 lectures. Retrieved 4 March 20I3. www.kalamullah.com/anwar-alawlaki.html

Bateson, Gregory and Margaret Mead. 1952. Childhood Rivalry in Bali and New Guinea. I7 min. New York: Penn State Media.

Connor, Linda, Patsy Asch, and Timothy Asch. I980. Jero on Jero: A Balinese Trance Seance Observed. $48 \mathrm{~min}$. Watertown: DER.

Deren, Maya. I985. Divine Horsemen: The Living Gods of Haiti. 52 min. New York: Mystic Fire Video.

Eisenstein, Sergei M. I928. October: Ten Days that Shook the World. IO4 min. Moscow: Sovkino.

Herzog, Werner. 1993. Bells from the Deep: Faith and Superstition in Russia. 60 min.Vienna: Werner Herzog Filmproduktion.

Khan, Nouman Ali. 2009. Literary Characteristics of the Quran. YouTube lecture. II8 min. Retrieved 7 March 20I3. www.youtube.com/watch? $=$ aWUy_luMqoQ

Kildea, Gary and Andrea Simon. 2005. Koriams Law and the Dead who Govern. IIo min. Canberra: ANU RSPAS Film Unit.

Rouch, Jean. I955. Les Maîtres Fous. 24 min. Paris: Films de la Pléiade. . I967. Jaguar. 93 min. Paris: Les Films de la Pléiade.

Rouch, Jean and Edgar Morin. 1961. Chronicle of a Summer. 85 min. Paris: Argos Films. 
Suhr, Christian and Mette Bahnsen. 2005. Want a Camel, Yes? 36 min. Aarhus: Persona Film. Thyrri, Irene and Martin Kjær Jensen. 20I6. Moskeerne bag sloret [The Mosques behind the Veil]. TV documentary, 4 episodes. Aarhus: Filmkompagniet and TV2.

Trinh, T. Minh-ha. 1982. Reassemblage. 40 min. New York: Women Make Movies.

Vachani, Nilita. I990. Eyes of Stone. 9I min. New Delhi: FilmSixteen and Doordarshan. Vertov, Dziga. I929. Man with a Movie Camera. 68 min. Kiev:VUFKU. 